\title{
De læste og læsende køn \\ - refleksioner over køn, litteratur og undervisning
}

I artiklen diskuteres potentialer og problemer $i$ forskellige retninger $i$ den litterare kvinde- og kønsforskning. De sattes ind $i$ en litterar responsteori, der kan vare med til at aibne for, bvordan kønnet kan tages $i$ anvendelse $i$ lasning og $i$ undervisningen.

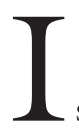

snart fire tiår

har den litterære kvinde- og kønsforskning udviklet forskellige teorier og metoder. Alligevel har denne forskning ikke sat sig mærkbare spor i didaktiske teorier og overvejelser over undervisningen i litteratur. For en kønsforsker kan det virke som en banalitet, at kønnet indvirker på læsningen af litteratur, ligesom elevens/studentens og underviserens køn har betydning i litteraturundervisningen. Men i didaktisk forskning synes usynliggørelsen af kønnet at være normen mere end undtagelsen. Spørgsmålet for mig er, hvordan kønnet indvirker på læsningen og undervisningen? Og hvordan kan læseren bruge sit køn i læsningen og undervisningen?

I denne artikel vil jeg reflektere over, hvordan den litterære kønsforskning ud fra forskellige teoretiske retninger indvirker forskelligt på læsningen af litteratur og på undervisningen. Indflydelserne fra disse retninger vil jeg videre reflektere over ved at inddrage dem i en litterær responsforsk- 
ning. Hensigten er at pege på mulige veje, så læseren kan bruge kønnet i læsningen af litteratur og i litteraturundervisningen.

Undervejs vil jeg eksemplificere med romanerne Syv Aar for Lea (1944) og April (1947/1961) af Sonja Hauberg. ${ }^{1}$

\section{LITTERÆR KØNSFORSKNING}

Den litterære kønsforskning har i høj grad været en litterær kvindeforskning. Læseren var en kvinde, og interessen var at læse og fortolke, hvordan kvinder blev fremstillet i litterære tekster og litteraturhistorier.

Læsningen af dansk (nordisk) litteratur med fokus på kønnet i teksten og læserens køn kan siges at have udkrystalliseret sig i tre retninger:
1) kønnet som kategori
2) kønnet som konstruktion
3 ) kønnet som dekonstruktion.

\section{KøNNET SOM KATEGORI}

Den litterære kvindeforskning begyndte i 1960'erne som en undersøgelse af kvinderoller og -billeder i den litteratur, der var skrevet af mandlige forfattere (Sørensen 1964, Christensen m.fl. 1972, Register 1977). Kvindelige læsere afslørede, hvordan mandsforfattere fremstillede kvinden som moder, madonna og luder. Kvinden læste sig selv i mandslitteraturen som det andet køn. En feministisk ideologikritisk læsning havde taget sin begyndelse.

Herfra var skridtet til at læse litteratur, der var skrevet af kvinder og om kvinder ikke langt at tage. Ældre og nyere kvindelitteratur blev fra 1970'erne læst med den hensigt at finde frem til, at kvindeforfattere var optaget af andre temaer og skrev på andre måder end mandsforfattere. Det var en kritisk læsning af, hvordan kvindelitteraturen kunne fastholde læseren i traditionelle kønsroller, og der blev stillet krav om, at kvindelitteraturen for at være god skulle indeholde forbilleder og fremstille utopiske modbilleder (Levy 1976, Richard 1976, Gaul 1978).

Læsninger af mands-/kvinderoller og billeder i litteraturen havde som forudsætning, at både forfatternes køn, de fiktive personers og læsernes køn kunne kategoriseres. Med kønnet som kategori var det fastlagt, at læseren kunne og skulle læse med erfaringer i eget køn. Resultatet blev en bekræftelse af kønsforskelle.

Potentialerne i læsninger med kønnet som kategori har været, at kvindeforfattere og deres tekster overhovedet blev synlige i litteraturforskningen. Det blev synligt, at tekster af kvindeforfattere kunne læses som kritik af de forhindringer, der satte sig igennem, når kvinder bevægede sig ud i offentligheden og ville være litterære producenter. Kvindeforskeres læsninger af deres kønsfæller gav rum for at belyse, hvordan kvindeforfattere blev skudt ud i periferien i kanoniseringen og hierarkiseringen af mandsforfattere. Ud af kvindelitteraturen læste kvindeforskere oprøret i kvindelige kreativitetsformer og skjulte skriftformer (Gilbert og Gubar 1979).

Problemet opstod, når kønnet som kategori blindt blev fastholdt som SEX, som biologisk køn og som udtryk for kvinders og mænds sande natur. ${ }^{2}$ En sådan læsning med kønnet som kategori lod sig dominere af det ensartede i kvinders liv, kvindelighed og kreativitet. Den fastholdt kvinden og manden i en binaritetstænkning, der resulterede i enten en nedvurdering eller en opvurdering af kvinden og det kvindelige.

Romanen Syv Aar for Lea har som hovedperson en pige, der pendler mellem rationelle og følelsesmæssige sider i tilværelsen. Hos en broder og i det matematiske gymnasium møder pigen det rationelle. Heroverfor sætter hun sine pigelige følelsesmæssige egenskaber.

Allerede med denne korte introduktion har jeg som læser taget en kategorisering i anvendelse, der bygger på velkendte kønspolariseringer, hvor det rationelle tilhører drengen, mens det følsomme føjes til pi- 
gen. Hermed bevares ikke alene en binær tænkning, men den løsrives også fra sin historiske og litterære kontekst. I læsningen gøres egenskaber i fremstillinger af drengen og pigen til noget, som tages for givet og naturligt, noget som ureflekteret tilskrives det at være født som dreng eller pige. Ydermere sker det med den følgevirkning for læsningen af pigen, at hun mystificeres som en gåde i det, der fra læserens side er tænkt som en afmystificerende sandhed om kønnet.

Potentialerne i denne læsning er, at der sættes fokus på romanpersonernes køn. Flere anmeldere af romanen lagde på udgivelsestidspunktet vægt på, at romanen drejede sig alment om ungdomsårene (Knudsen 1989, s. 229). På den baggrund roste de romanen; men de usynliggjorde unægteligt også de kønsperspektiver, der er til debat i romanen.

Kønnet som kategori har gjort det muligt at få øje på, at valg af hovedpersonens og bipersonens køn signalerer betydninger i den litterære tekst. Men fastfryses læsningen af betydninger til statiske kønsstørrelser, negligeres processer i teksten, hvor der sker forskydninger af køn i teksten.

\section{KØNNET SOM KONSTRUKTION}

Kønnet som konstruktion i den litterære kvindeforskning var inspireret af historiske, sociologiske og psykologiske teorier. Kønnet blev brugt til at læse, hvordan de kvindelitterære tekster på forskellige historiske tidspunkter kunne sige noget om kvindernes positioner og reaktioner. Kønnet blev læst som en konstruktion, der var formet af samfundet og dets institutioner (familien, skolen etc.) på et givet historisk tidspunkt. Samtidig blev kønsforskelle og kønsforhold set som konstruktioner, der var udformet af kvinder og mænd, og som derfor også kunne udvikles over historisk tid. Kønnet blev læst som GENDER, som socialt og kulturelt køn.

Identitet blev et gentaget tema i kvinde- lige læsninger af kvindelige tekster. Temaets variationer over tid blev belyst med eksempler fra den romantiske, den realistiske og den modernistiske kvindelitteratur (Jensen 1993, Dahlerup 1983, Richard 1979). Det blev en (gender)læsning af gennembrudskvinder, kvinder i offentligheden og kvinder mellem kvindelige og mandlige positioner (Dahlerup 1983, Richard 1978, Knudsen 1989).

På denne baggrund kan Syv Aar for Lea læses i "dialog" med debatter i samtiden om kvindens situation og socialisation. De rationelle og de følelsesmæssige sider er begge til stede i hovedpersonen, der er en pige med opvækst i mellemkrigstiden.

Læseren følger hovedpersonen Ruth fra førskolealderen til studentereksamen. Tidligt oplever hun konflikter i forholdet til broderen Svend. Han er fremstillet som drengen, der i kraft af sit køn påvirker Ruth med sin rationalitet og tilstedeværelse i virkeligheden. Ruth vil på mange måder gerne være som Svend. Hun vil imidlertid også have sine pigelege og drømme, og hun afviser ham, når han nysgerrigt spørger til hendes lege.

Barndommens konflikter følger hovedpersonen ind i ungdommen. Hun lever mellem at være sig bevidst om sin tilværelse som en pige med behov for følelser og nærvær på den ene side og på den anden side med ønsket om som drengen at være en rationel og distanceret person. Hun vælger at blive matematisk student og kaster sig med ildhu ind $\mathrm{i}$ diskussioner med drengene om matematikkens af- og begrænsninger i forhold til eksistensspørgsmål. I forelskelsen søger hun derimod oplevelser af irrationalitet og grænseløshed.

I min læsning af romanen indskriver den sig i samtidens debatter $i$ fremstillingen af pigen, som vil være både pige og dreng (Knudsen 1989, s. 229 ff.). Kvinden i mellemlaget blev fra midten af det 20.århundrede af flere offentligt debatterende og skrivende kvinder og mænd placeret mellem ude- og hjemmearbejde og mellem 
mands- og kvindepositioner. I denne roman bliver matematikkens rationelle grænsedragninger sat til diskussion, og den kvindelige hovedperson viser, hvordan en pige ikke trives i det matematiske gymnasium. Samtidig giver romanen en indsigt $i$, at det matematiske gymnasiums opdragelse til rationel tænkning er nødvendig for pigens videre udvikling i samtiden.

Kønnet indvirker på læsningen i mit valg af synsvinkel, idet læsningen foregår med reference til dels det sociale køn i tiden (de kønsopdelte lege, det kønsopdelte gymnasium), dels nyere teorier om det kulturelle køn (pigens oplevelse af identitetskonflikter og forestillinger om køn). Men kønssynsvinklen er samtidig bestemt af romanen, hvor Ruth fremstilles som en hovedperson, der bevæger sig mellem drøm, nærvær og følelser (konstruktionen af pigens verden) OG virkelighed, distance og rationalitet (konstruktionen af drengens verden).

Potentialerne i læsningen af kønnet som konstruktion har været, at den kunne opfange de historiske kønsbetingelser og -ændringer. Kønnet blev læst som skabt i tiden. Samtidig kunne kønnet med litteraturen som filter læses som afprøvninger af nye veje og positioner.

En sådan konstruktiv læsning havde imidlertid også sine begrænsninger. Med kvinden som konstruktør risikerede læsningen at blive kønsblind. Når kvinden læste kvinden, læste hun i sit eget spejlbillede. Det blev hurtigt til en identificerende og sympatisk læsning. Når kvinden læste kvinden, kunne hun ikke læse det fremmede og det konfronterende. Kvinden kunne ikke læse manden, eller hun kunne kun læse manden ud fra en kvindelig ensidig læsning. Denne læsning var påvirket af strukturteorier, hvor køn blev reduceret til tænkning i binariteter (kvindelig-mandlig, drøm-virkelighed etc.). På sin vis kunne denne retning siges at fortsætte kategoriseringen af kønnet; men til forskel fra den første retnings fastholdelse af de biologiske køn blev den anden retning en læsning af kvindeligheden som en historisk kategori, der er konstrueret. ${ }^{3}$

\section{KØNNET SOM DEKONSTRUKTION}

Fra midten af 1980'erne tog kvindelitteraturforskere afsæt i kønsblindheden. Med dekonstruktionen blev kategoriseringer og konstruktioner af kvinden og manden, kvindeligheden og mandligheden sat på prøve. Læsninger af såvel biologisk, socialt som kulturelt køn blev dekonstrueret, nedbrudt og opløst. Den kvindelige litteraturforsker læste, hvordan andre kvindeforskere havde fejllæst litteratur, der var skrevet af mands- og kvindeforfattere. Kønnets indvirkning på læsningen blev brugt til at vise, hvordan kønnet i litteraturen og i læserens læsning af litteraturen blev igangsat i interaktionen mellem tekst og læser. Køn i litteraturen og i læsningen skulle tages som udtryk for kønnets iscenesættelse i tekstens fiktive univers og i læserens læsninger. Kønnet i litteraturen og i læseren blev læst som "maskeradeagtigt" og altid på flugt fra såvel kategoriseringer som konstruktioner (Engberg og Thomsen, red. 1992, Palsnov 1986). Kønnet blev læst som SYMBOLSK. Kønnet i litteraturen var og måtte læses som udtryk for æstetiske og retoriske diskurser. Den dekonstruktive læsning betød en forskydning fra udsagnets, temaets betydning til udsigelsens, udtrykkenes muligheder. Kønnet i læseren blev læst som retorisk flertydigt og flygtigt.

I min læsning af Syv Aar for Lea på de foregående sider består blindheden $\mathrm{i}$, at der ikke bliver spurgt til fortællerens og læserens iscenesættelse af hovedpersonens polarisering af pige- og drengeverdenen. Fiktionen bliver læst med reference til konstruktioner i en historisk virkelighed og ikke som en litterær diskurs. Læst som litteratur kan læseren spørge: Hvilken symbolsk betydning har det, at hovedpersonen bliver fremstillet af en 3. persons fortæller, der gengiver hovedpersonens udvikling, således at der skabes distance mellem fortælleren og 
hovedpersonen? Stoler læseren på denne fortæller? Hvad gør fortælleren med læseren, og hvad gør læseren med fortælleren? Hvilken symbolsk betydning har det, at distancen af og til afbrydes af indre monologer, hvor hovedpersonen bliver fortælleren? Skaber fortælleren eller læseren nærvær, således at en kvindelig læser i højere grad end en mandlig læser lader sig opsluge af den kvindelige 1. persons fortællers farvede fremstilling?

Med kønnet som dekonstruktion var det kønnet som udtryk for en række forskelle, der indvirkede på læsningen. Læseren 'gik ind i' teksten, hvor den virkede fragmentarisk, afbrudt og flertydig. Læsningen blev dynamisk, idet den hele tiden udfordrede andres læsninger, udfordrede de kønspositioner, som andre læsere indtog. Læseren rejste spørgsmål og gav ingen færdige løsninger på tekstens vegne.

Problemet med den dekonstruktive læsning kom, når denne læsning blot resulterede i læsningen af andre læseres kønsblindhed. Med inspiration fra teorier af Jacques Derrida blev binære kønslæsninger opløst og forskudt. Det resulterede i, at begreber som kvindeligt og mandligt i de mest radikal dekonstruktivistiske læsninger forsvandt, og i de mere moderat dekonstruktivistiske læsninger blev forsynet med citationstegn. Dermed opstod der en vis blindhed overfor, at dekonstruktionen kunne føre til en konstruktion af kønsneutrale og almenmenneskelige læsninger. Når læseren for at undgå kategoriseringer og konstruktioner blot nøjedes med at nedbryde kønnet, så blev kønnet usynliggjort og ikke-eksisterende i teksten og i interaktionen mellem tekst og læser. Hermed stødte dekonstruktionen mod en grænse, hvor kønnet sprogligt og litterært set afgik ved døden.

I den litterære kønsforskning i 1990'erne med fokus på kvindeforfatteres tekster bliver kønnet læst som konstrueret i dekonstruktionen. Dekonstruktionen bliver anvendt til at opløse kønnet for at blive op- mærksom på, hvad og hvordan det anderledes i konstruktionen af køn kan bidrage til at sætte perspektiver på kønnets flertydighed og fluiditet. Kønnet bliver læst som udtryk for en række forskelle, der er kontekstbestemte. I interaktionen mellem tekst og læser skaber læseren kønskonstruktioner ved at situere dem i idéhistoriske eller genrehistoriske diskurser og i tekstnære læsninger af litterære diskurser. De kan anvendes til at vise, hvordan kønsstereotypier bryder sammen, og visioner dukker op (Sanderhoff 1998).

\section{LITTERÆR RESPONSFORSKNING}

I de foregående afsnit har jeg præsenteret forskningsretninger, hvor kønnet er placeret $\mathrm{i}$ forfeltet. I artiklens videre forløb anvendes disse retninger til at præsentere en litterær responsforskning, hvor kønnets betydning ikke er inddraget. Hermed vil jeg søge at belyse, hvordan kønnet kan bruges i litteraturlæsningen og -undervisningen.

Afsættet er litteraturteoretikeren Wolfgang Isers anvendelse af begrebet projektion (Iser 1976 og 1978). Mest konkret skriver han om projektion i den moderne litteratur, hvor projektioner benyttes til at konfrontere læseren med egne forventninger i læsningen. Projektion anvender jeg her i betydningen, at en person tilskriver de fiktive personer eller en litterær tekst motiver, som tilhører ham/hende selv. I læsningen kiler læseren sig med sine projektioner ind i teksten (Knudsen 1994).4 Iser omtaler mere generelt, at tomme pladser i en litterær tekst kan udfyldes af læseren, og at interaktionen mellem tekst og læser kommer i stand gennem læseprocesser, der involverer læserens vandrende synspunkt.

Wolfgang Iser præsenterer en responsteori, hvor det er teksten, der sætter rammerne for læserens læsninger. Læseren svarer på teksten med fortolkninger, således at der opstår en interaktion mellem teksten og læseren. ${ }^{5}$ Iser har inspireret mig til at se på 
tre former for projektioner i den litterære responsforskning:

1) projektioner som bekrxftes, idet opmærksomheden rettes mod det genkendelige

2) projektioner som indkredses, idet læseren aktiveres ved hjælp af skæreteknikker i teksten fx afbrudte handlingsforløb og fortællerskift

3) projektioner som konfrontation, idet læseren uafbrudt forvirres af tekstens stadig skiftende forløb, fortællere, synsvinkler, billeder m.m.

\section{PROJEKTIONER SOM BEKRÆFTES}

I den første form for projektion vil jeg med kønsperspektivet sige, at læseren bliver bekræftet i sit kønssyn. Den kvindelige læser identificerer sig med hovedpersonen i Syv Aar for Lea. Hun læser med genkendelse om en piges konflikter og pendlen mellem pige- og drengeverdner.

Til denne type projektion knytter der sig en realistisk litteratur, hvor teksten appellerer til at blive læst som et autentisk udsagn om personer og miljøer. Velegnet læsning er eksempelvis naturalismens problemdebatterende litteratur, der er orienteret mod at synliggøre sandheden om kønnet, manden/kvinden og mandligheden/kvindeligheden. Lxseren kan i den realistiske litteratur tildeles en tryg plads, når forfatteren styrer, hvordan kønnet skal læses og forstås. Kønnet fremstilles i kategorier, der bekræfter kønsroller og undertrykkelsesmønstre. I denne litteratur bliver den kvindelige hovedperson placeret i genkendelige omgivelser, og hendes oplevelser og adfærd bliver forklaret for læseren. Læseren forventer at blive bekræftet i opfattelser af sit eget køns problemer og $\mathrm{i}$ beskrivelser af konflikter med det andet køn.

I litteraturundervisningen kan projektioner, som bekræftes, anvendes i det første møde med den litterære tekst. Her er udgangspunktet, at læseren udfolder sin læsning ud fra det sted/de steder i teksten, der er genkendelige, og hvor han/hun oplever at blive bekræftet. Læseren sætter ord på sit sted og reflekterer over, hvad der gør, at han/hun er stoppet op på dette sted $\mathrm{i}$ teksten. Denne første refleksion og mødet med de andre læseres refleksioner i undervisningsrummet sker ved hjælp af kategoriseringer af pige-dreng og kvinde-mand, hvis kønnet er sat på dagsordenen for undervisningen.

I romanen Syv Aar for Lea gør jeg det som læser ved at sætte fokus på hovedpersonen på det sted i teksten, hvor hendes splittelse mellem det rationelle og det følsomme bliver introduceret. Det sker i begyndelsen af romanen og $\mathrm{i}$ en psykologisk realistisk fremstilling, hvor tanker og sanser igangsættes i læseren. Mit fokus som læser sættes på en drengepige. En sådan læsning siger noget om den subjektive læser, men i og med at den i undervisningen viser sig at have træk til fælles med nogle læsere og at adskille sig fra andre læseres fokus, opstår der refleksioner i rummet, der kan føre til nysgerrige indkredsninger af egne og andres læsninger $i$ forhold til romanen. 5

\section{PROJEKTIONER SOM INDKREDSES}

I projektioner som indkredses vil læseren aktivt udfylde tekstens tomme pladser ved fx afbrudte handlingsforløb og fortællerskift. Indkredsningerne kan gradvist blive til en organisering af tekstens udsagn og udsigelse. ${ }^{7}$ Læseren kan bruge sit køn til at konstruere tekstens antydninger af kønnets betydninger.

Denne type projektioner kræver en litteratur, hvor organiseringen af udsagn og udsigelser overlades til læseren. En sådan litteratur vil have flere indgange og tåler genlæsninger, idet teksten stadig vil åbne for nye læsningsmuligheder. ${ }^{8}$ Eksempelvis præsenteres læseren i Syv Aar for Lea for fragmenter af virkeligheden, som han/hun med sit køn må "se” og "sanse” gennem 
hovedpersonens oplevelser og forestillinger. Beskrivelserne af en pige på vej mod at udvikle sig til en kvinde skabes ved at skifte mellem at se hovedpersonen ude- og indefra. Skiftene markeres af og til med nyt afsnit. Af og til glider læseren fra en auktorial (ydre) til en personal (indre) synsvinkel. Men en nærmere læsning viser præcist, hvor skiftene mellem den auktoriale og den personale synsvinkel sker, og den opmærksomme læser registrerer skiftene som tomme pladser, hvor han/hun kan være meddigtende.

Med en auktorial (3. persons) fortæller skabes der i denne roman en distance mellem hovedpersonen, fortælleren og læseren. Læseren "ser" som fortælleren på hovedpersonen udefra og forstår, at der er tale om udvælgelser og kombinationer af situationer. Men der skabes også en distance mellem fortælleren og læseren, når skiftene mellem fortællerens distance (ydre synsvinkel) og fortællerens nærvær (indre synsvinkel) indgår i læserens indkredsninger af kønnets identitetskonflikter og i udviklingen af en drengepiges identitet.

Kønslæsningen i de tomme pladser kan i Syv Aar for Lea også anvendes til at indkredse, hvordan bipersoner og billeder knyttes sammen med køn, død og kunst. To drenge brænder ihjel på det tidspunkt, hvor hovedpersonen indleder sin pubertet. Lxseren indkredser hovedpersonens alder og det, at drengene skal dø i en ildebrand. Drengenes død symboliserer, at det så at sige brænder på for pigen, der i et stykke tid har følt sig mest tiltrukket af drengeverdenen. Ved overgangen til puberteten må hun indkredse normer for kvindelig adfærd. Det gør hun ved i psykologisk forstand at slå sine drengesider ihjel.

Den eneste pige, som hovedpersonen i barndommen er knyttet til, har sans for drømme og skønhed. Men hun er syg og unormal. Hendes død præsenteres i romanens ungdomsdel, og læseren får et indtryk af, at de pigelige drømme er utilstrækkelige for en begavet mellemlagspige. Såvel det alt for drengede som det alt for pigede dør i denne roman, godtgør læsningen af dødsfaldene i romanen sammenholdt med de steder, som de bliver præsenteret og de måder, som de bliver fremstillet på.

Det drengede og det pigede er kønskonstruktioner, der samtidig giver romanen dens kunstneriske udformning. Kunst drejer sig i denne roman og i min læsning af romanen om at udnytte pigens drømme, der giver adgang til sindets følelsesmæssige, uendelige og ubekendte muligheder i kombinationer med drengens/broderens matematisk rationelle grænsetænkning. At skrive og læse litteratur kræver både at turde se sindets sider og at være i stand til struktureret at skrive og læse om det ubekendte. Romanen bliver herved på en og samme gang en konstruktion af køn og af kunst.

\section{PROJEKTIONER SOM KONFRONTATION}

Projektioner for at konfrontere læseren med egne projektive læseforventninger finder Wolfgang Iser i den modernistiske litteratur, og han nævner som eksempel Ulysses af James Joyce.

Når læseren bliver konfronteret med egne forventninger, kan projektionen indebære, at læseren forkaster teksten som uforståelig. Læseren vil ikke læse teksten eller vil springe de steder over, hvor teksten forekommer at være for forvirrende. Hvordan fremstillinger af kønnet bliver anvendt til at forvirre læseren, findes der eksempler på i litteraturen og litteraturforskningen ( $\mathrm{fx}$ Brantenberg 1977, Felman 1981).

Romanen April af Sonja Hauberg er et eksempel på en tidlig modernistisk tekst, hvor skift i fortælletid og -rum forvirrer læseren. Romanen foregår på to tidsplaner. På nutidsplanet præsenteres læseren for en kvindelig hovedperson på rejse. Der er tale om fremstillingen af en ydre rejse med en ganske banal handling: En ung kvinde har problemer med sit kxrlighedsliv og søger ud på landet for at tage ferie fra sine problemer. 
På datidsplanet sættes læseren på en prøve, idet handlingen ofte bliver afbrudt af fragmentariske skitser og til slut af et digt. Her skifter fortællere, bipersoner og billeder, så læseren må stoppe op for at søge at sammensætte, hvor den kvindelige hovedperson befinder sig på sin ydre rejse. I romanens første kapitel vil læseren eksempelvis være i tvivl om, hvorvidt hovedpersonens møde med en mand skal udtrykke en realoplevelse eller en iscenesat oplevelse.

De mandlige bipersoner bliver i denne roman udsat for vrede, humor og tilbedelse, så læseren forsøger at indkredse, hvordan to så forskellige køn kan mødes. Men indkredsningen bliver et uendeligt læserarbejde, idet læserens konstruktioner straks nedbrydes af skift i tid og rum. Såvel kvinde-som mandskønnet bliver i denne roman til stadighed udsat for ændrede beskrivelser og placeringer.

Wolfgang Iser kan ikke siges at være dekonstruktivist, sådan som projektioner som konfrontation måske synes at pege på. Tværtimod er hans ærinde at bevæge sig mod en stadig mere helhedsintegrerende læsning, hvor tekstens komplekse mønstre i mødet med læseren konstrueres/organiseres i en meningsfuld sammenhæng.

Dekonstruktionen kan da inspirere til at åbne det alt for lukkede i Wolfgang Isers responsteori ved at sætte fokus på, hvordan tekstelementer unddrager sig og gør modstand mod en lukket læsning. Her kan der tages et opgør med helhedsorienterede fortolkninger og med ideologikritiske analyser af sande og falske læsninger (Felman 1982). Der findes ikke en rigtig læsning, heller ikke en rigtig læsning af kønnet vil den dekonstruktivistiske læser sige. I højden kan læseren præstere en læsning som kommende læsere ikke kan undgå at inddrage. Den læsning vil være præget af at være anderledes end foregående læsninger, og den vil tage fat der, hvor teksten ikke vil læses, og hvor læseren ikke vil læse. Hermed kan vejene åbne sig for at spørge, hvor vil læseren ikke læse? Og hvor sætter kønsblindheden ind?

Projektioner som konfrontation vil jeg sammenholde med den pædagogik, der er blevet kaldt "en anfægtelsens pædagogik" (Weinreich 1992, s. 192). Med et sådant pædagogisk afsæet bliver deltagerne i undervisningen mødt af modbilleder og fremmedartede elementer. I litteraturundervisningen præsenteres genrer og litterære begreber, der skal udfordre og anfægte deltagerne. Hermed kan der åbnes for en pædagogik, hvor kønnet kan konstrueres på sådanne måder, at også kønnet i litteraturen og litteraturundervisningen bliver anfægtet. Konstruktionen er her i høj grad at forstå som en sproglig italesæettelse, hvor udfordringen for kønnet ligger $\mathrm{i}$ at afdække, hvordan køn i sproget handler om magt, magt-over og magt-til. 9

I undervisningen vil man med en anfægtelsens pædagogik nærme sig en dekonstruktion af kønsforskelle. Problemet kan blive, at dekonstruktionen er med til at usynliggøre kønnet. Nedbrydningen af forskelle vil ske på trods af kønnets tilstedeværelse i konkrete piger/kvinder og drenge/mænd og på trods af kønsadfærd i undervisningsrummet. Med et dekonstruktivt blik vil en sådan usynliggørelse imidlertid være grund nok til at tage kønnet op som det, der ikke er tilladt at tale om i litteraturundervisningen, og som det der i litteraturen og læseren yder modstand.

Med et dekonstruktivt blik kan forskelle blive nuanceret som en række kønsforskelle. Litteraturlæsningen vil i en nutidig undervisning kunne inddrage elevernes og de studerendes oplevelser og erfaringer med kønnet som noget mangfoldigt og flertydigt. I stedet for at beklage denne udvikling kan de mange kønsforandringer være de muligheder i undervisningen, der skiftevis tillader læseren at læse og bruge kønnet som bekræftende kategorisering, som indkredsende konstruktion og som konfronterende dekonstruktion. 


\section{AFSLUTNING}

De forskellige retninger $\mathrm{i}$ den litterære kønsforskning, som jeg har skitseret, viser, hvordan kønnet indvirker på læsningen af litteratur, og hvordan læsningen afhænger af den valgte retning. Enhver retning giver med forskellige synsvinkler muligheder for og begrænsninger i læsninger af kønnet.

De mulige måder, som læserens køn kan blive brugt i lesningen af litteratur og undervisningen, kan indkredses ved hjælp af en litterær responsforskning, der viser, hvordan læseren og teksten træder i interaktion med hinanden i projektioner som bekræftes, som indkredses og som konfrontation. Når trådene trækkes fra kønnet som kategori til projektionen som bekræftes, fra kønnet som konstruktion til projektionen som indkredses og fra kønnet som dekonstruktion til projektionen som konfrontation, vil litteraturundervisningen blive mere nuanceret, end den er i dagens didaktiske teorier og i dagens undervisningsrum.

Der tales om læsekompetence i litteraturundervisningen. Denne kompetence opnås ved en stadig større indsigt i litteraturens særlige sprog og virkemidler. Den udvikler sig ved hjxlp af stadig større indsigt i mulige teorier, som læserne kan tage i anvendelse i læsningen og undervisningen. På tilsvarende måde kan kompetence $\mathrm{i}$ køn siges at være en øvelse $i$ at læse kønnets særlige sprog og virkemidler. Denne kompetence i kønnets betydninger kan udvikles ved at tage de mange mulige retninger og teorier $\mathrm{i}$ kønslitterær forskning i anvendelse.

Kønnet er noget som alle har, oplever med og tænker på - men alt for sjældent bruger i læsningen af litteratur og i litteraturundervisningen. Den er en resurse, der kræver øvelse for at blive til en kompetence. I litteraturundervisningen er der lige så mange muligheder, som der er elever/studerende og undervisere til stede, for at deltagerne kan øve sig i at mødes med det samme køn, med det fremmede $\mathrm{k} ø \mathrm{n}$ og med udtryk for en række kønsforskelle.

\section{NOTER}

1. Romanen April blev skrevet, mens Sonja Haubergs lå for døden. Hun døde i 1947, men romanen udkom først i 1961.

2. Kun få kvindelitterære forskere i Danmark har ensidigt fastholdt en biologisk tænkning og da som oftest med inspiration i den franske, feministiske psykoanalytiker Hélène Cixous, fx Jensen 1987.

3 . "Kvindeligheden som historisk kategori" var titlen på et tværfagligt emne, som jeg var med til at igangsætte på Odense Universitet i slutningen af 1970'erne, og som mundede ud i et landsdækkende temaseminar og udgivelsen af artikler i bogen Overgangskvinden, red. Mette Bryld m.fl. (1982). 4. Iser er her inspireret af gestaltteori. Herom skriver jeg kort i Fodspor og vingesus (1996), der er en undervisningsbog i nyere litteraturpædagogik. Under udarbejdelse har jeg en bog, hvor jeg teoretisk udreder disse begreber til brug i en nyere litteraturpædagogik.

5. Wolfgang Iser gør på den ene side op med en nykritisk nærlæsning af teksten (autonomiteorien om tekstens selvgyldige eksistens) og på den anden side en receptionsteoretisk ensidig læserorientering.

6. Jeg bygger på undervisning med studerende af begge køn på universitetet og på Danmarks Lærerhøjskole samt på tilbagemeldinger fra lærere, der har anvendt mine forslag til øvelser i Fodspor og vingesus, s. 46-51.

7. Læsningen bliver en konstant proces, der involverer læserens vandrende synspunkt, tekstens ubestemtheder og tomme pladser. Læsningen bliver udtryk for en sammenhængsstræbende helhedsorganisering, hvor læsningen i stadig fornyede læsninger bliver mere og mere kompetent og varieret. Hvad der i en læsning er det udvalgte sted og kommer til at stå i forgrunden, kan i den næste læsning blive baggrunden for en ny forgrund. 8. Indgange anvender jeg som begreb for at undgå hierarkiserende begreber som lag og niveauer i læsningen af litteratur.

9. Her er jeg inspireret af Patti Lather's anvendelse af begrebet empowerment, som hun definerer i forbindelsen "the politics of empowerment" (1991). Hun mener, at det kan anvendes til at analysere ideer om årsager til magtesløshed, til at opdage undertrykkende kræfter og til at handle både individuelt og kollektivt for at ændre livsbetingelserne. Endvidere definerer hun empowerment som en proces, hvor den enkelte forpligter sig på egen magt-over og indsigt i egen magt-til. 


\section{LITTERATURLISTE}

- Andreassen, Margrethe (1989): “Den tredje skønhed. Om den androgyne figur hos Kirsten Thorup" i Den tredie skønhed, red. Linda Andersen m.fl., Aarhus Universitetsforlag, Århus.

- Brantenberg, Gerd (1977): Egalias døtre, Pax forlag, Oslo.

- Bryld, Mette m.fl., red. (1982): Overgangskvinden, Odense Universitetsforlag, Odense.

. Christensen, Annelise m.fl.(1972): "Kønspolitik"

i Kritik 22, Fremad, København.

- Dahlerup, Pil (1983): Det moderne gennembruds kvinder, Gyldendal, København.

- Engberg, Charlotte og Thomsen, Bodil Marie, red. (1992): Maskerade. Kulturstudier nr. 10, Århus.

- Felman, Shoshana (1981): "Rereading Femininity" i Yale French Studies 62, 15.

- Felman, Shoshana (1982): "Turning the Screw of Interpretation" i Shoshana Felman, red. Literature and Psychoanalysis, The Johns Hopkins University Press, Baltimore og London.

- Gaul, Bente (1978): Undertrykkelse og modstand $i$ den nye kvinderoman, Gyldendal, København.

- Gilbert, Sandra M. og Gubar, Susan (1979): The Madwoman in the Attic, Yale University Press, New Haven og London.

- Hauberg, Sonja (1944): Syv Aar for Lea, Gyldendal, København.

· Hauberg, Sonja (1961): April, Gyldendal, København.

- Iser, Wolfgang (1976): Der Akt des Lesens, München.

- Iser, Wolfgang (1978): The Act of Reading, The Johns Hopkins University Press, Baltimore og London.

- Jensen, Lise Busk (1993): "Det elskværdigste i skabningen. Romantikkens kvindelige tekst" i Nordisk kvindelitteraturhistorie bd.1, s. 143-56, Rosinante, Købehavn.

- Jensen, Merete Stistrup (1987): Kvindesprog, Aalborg Universitetsforlag, Ålborg.

- Knudsen, Susanne V. (1996) Fodspor og vingesus. Litteraturpedagogik, Munksgaard, København.

- Knudsen, Susanne (1989): IMELLEM - skidt og skrift, Gyldendal, København.

- Knudsen, Susanne V. (1994): "Med gestaltpædagogisk hilsen - litteraturundervisning, inspireret af gestaltpædagogik" i På vej mod en ny litteraturpedagogik, Thorkild Borup Jensen m.fl., red., Kroghs Forlag, Kolding.

- Lather, Patti (1991): Getting Smart. Feminist Research and Pedagogy With/in the Postmodern, New York og London.
- Levy, Jette Lundby (1976): De knuste spejle, Tiderne Skifter, København.

- Palsnov, Gitte (1986): "Karen Blixen og den erotiske dimension" i Dametur, Vibeke Aarestrup m.fl., red., Aarhus Universitetsforlag, Århus.

- Register, Cheri (1977): Kvinnokamp och litteratur $i$ USA och Sverige, Rabén \& Sjögren, Ystad.

- Richard, Anne Birgitte (1976): Kvindelitteratur og kvindesituation, Gyldendal, København.

- Richard, Anne Birgitte (1978): Kvindeoffentlighed 1968-75, Gyldendal, København.

- Richard, Anne Birgitte (1979): På sporet af den tabte hverdag. Om Dorrit Willumsens forfatterskab og den moderne virkelighed, Gyldendal, København.

- Sanderhoff, Rikke (1998): "Den listige jomfru. En dekonstruktion af Charlotte Dorothea Biehls komedie Den listige optrækkerske" i Kvinder Køn \& Forskning 3/98, København.

- Sørensen, Lise (1964): Digternes damer, Gyldendal, København.

- Weinreich, Torben (1992): Askepots sko. Børnelitteratur og litteraturpadagogik 1965-1990, Danmarks Lærerhøjskole, København.

\section{SUMMARY}

The article discusses three different tendencies of research in gender and literature. These are presented as sex, referring to the way we categorise women and men as biological beings; gender as construction; and deconstruction of gender binaries.

These tendencies are applied to theories of aesthetic responses as Wolfgang Iser presents them in his book The Act of Reading. Iser's focus on reading as projection has inspired the author to improve three different modes of projection related to the different tendencies of research in gender and literature.

Throughout the article reflects on the use gender in reading and teaching literature; it offers no simple answer, but more possibilities.

Susanne V. Knudsen, dr.phil.

Lektor,

Danmarks Lærerhøjskole 